\title{
Chapter 8 - In pursuit of a common values base for working with young people in formal, informal and social learning
}

\section{Julie Rippingale}

\section{Introduction}

This chapter advocates a common value base and framework for working with young people in formal, informal and social learning. These three learning spheres will be defined in the context of young people's lives, with the premise that young people will experience all of these forms of learning but, dependent upon the educator (be that a youth worker, social worker or teacher), a different values base and ethos will be evident. A standard value base of caring for and caring about, young people (Noddings 2002) is advocated. This value base underpins a common framework for working with young people as defined by Smith (2012) as 'animation' - bringing 'life' into situations - often achieved through offering new experiences; 'reflection', creating moments and spaces to explore lived experience; and 'action', working with young people so that they are able to make changes in their lives. The theories underpinning the implementation of such a framework will be discussed and potential conflicts acknowledged. Vignettes will illustrate how the framework and value base will facilitate the emancipatory capacity of learning and its ability to act as an agent of social change. Re-imagining ways of working with young people and lessons for practice will conclude the chapter.

\section{Defining formal, informal and social learning}

Young people spend a great deal of their time learning within different contexts and with different people, including their peers. The first sphere is perhaps the most obvious in the context of young people's lives; formal learning, which takes place in settings such as schools, colleges and universities. This was defined by Freire (1996) as a narrative form of learning he termed the 'banking' concept of education. Within formal education the teacher is the narrator and the student the patient, listening learner who waits for the teacher to deposit knowledge in him/her. The task of the teacher is to 'fill' the students with the contents of his/her narration. These contents are, however, without any life and the narrative is to be memorized by the students. This is illustrated by Freire as follows: 
The outstanding characteristic of this narrative education, then, is the sonority of words, not their transforming power. 'Four times four is sixteen; the capital of Pará is Belém.' The student records, memorizes, and repeats these phrases without perceiving what four time four really means, or realizing the true significance of 'capital' in the affirmation 'the capital of Pará is Belém,' that is, what Belém means for Pará and what Pará means for Brazil. (Freire 1996: 52)

In contrast to this banking concept of education is informal learning, which takes place in the context of young people's lives in a range of settings. These include places such as youth projects, community centres and health projects. Informal education is distinct in that it is a two-way process involving conversation and dialogue where the role of both learner and educator are of equal significance. Learning occurs from everyday problem posing of issues which are of immediate importance to those involved (Batsleer 2008). Informal learning recognizes and values the ideas, resources and community-based assets that young people bring to the process of informal learning. Freire (2006) termed this form of education problem-posing education.

Through dialogue the teacher-of-the-students and the students-of-the-teacher cease to exist and a new term emerges: teacher-student with studentsteachers. The teacher is no longer merely the one-who-teaches but the one who is himself taught in dialogue with the students, who in turn while being taught also teach. They become jointly responsible for a process in which all grow. In this process, arguments based on 'authority' are no longer valid; in order to function, authority must be on the side of freedom not against it. Here, no one teaches another, nor is anyone self taught. People teach each other mediated by the world, by the cognizable objects which in banking education are 'owned' by the teacher. (Freire 2006:80 - emphases in original)

Informal education engages the passions and emotions of young people as well as their thoughts (Batsleer 2008). Dewey (1963) distinguishes formal learning as a 
process of preparation for future living whilst informal education is a social process a process of living.

The third sphere is social learning of which concepts vary and can be somewhat broad (Hoppitt and Laland 2013). Early definitions by Bandura (1977) concluded that social learning concerned individual learning which took place in a social context influenced by social norms. Smith (2003/2009) summarizes that social learning is situational in that it involves interaction and or observation in social contexts. It involves movement from the margins to the centre of a community of practice and is underpinned by conversation and participation. This view is echoed by Hoppitt and Laland: 'Social Learning is learning that is facilitated by observation of, or interaction with another individual (or its products)' (Hoppitt and Laland 2013: 4). As much of young people's lives are social, it can therefore be anticipated that much learning will be undertaken in this sphere. Whilst practitioners may not be directly involved in this learning, they will, through the spheres of formal and informal learning, become aware of some of the social learning taking place.

Reed et al (2010) argue that for learning to be considered social learning the process must be able to:

1. Demonstrate that a change in understanding has taken place in the individuals involved;

2. Demonstrate that this change goes beyond the individual and becomes situated within wider social units or communities of practice; and

3. Occur through social interactions and processes between actors within a social network. (Reed et al 2010: online)

Thus, in the context of young people's lives and learning, social learning is for many the most prevalent and may occur both within and outside of formal and informal learning spheres. Similarities can be drawn between the three different spheres of learning. All involve engagement at some level by the participants and involve the role of the 'educator' in one form or other. Fundamentally they involve at least two people. It is with this in mind that the following common value base of care is promoted. 


\section{A common value base of care}

\section{Notions of care}

A common value base which excludes any other professional value base is not being advocated here. Practitioners facilitating the different spheres of learning will operate from their own value base relevant to the context of their professional work - for example, in the case of teachers, youth workers, social workers and health workers. However, to have a common value base throughout the learning spheres of 'care' for and about young people is important, and has the potential to transform young people's experiences in these learning spheres. It is therefore important to explore what 'care' is and how this might be implemented.

Human beings who are put together properly care. Care, the process of listening to another's world and understanding why things are that way for them, understanding what they need or are asking for, is a deep and powerful ethical driver which may conflict with the objective and abstract definitions of justice. (Sercombe 2010: 150 - emphasis in original)

This is echoed by Allmark who states that 'Caring is not good in itself, but only when it is for the right things and expressed in the right way' (Allmark 1995:19). Thus, care is not enough on its own, and must be measured with ethics and the requirements of justice. Sercombe (2010) affirms two important forms of justice: communicative and distributive. Communicative justice is concerned with the fair application of sanctions (both rewards and penalties) whilst distributive justice considers the fair distribution of the benefits and burdens of social life. This form of justice considers notions of discrimination and positive discrimination, equality and equity. Within the learning spheres practitioners who care for and about young people should seek to challenge and not to replicate the injustices that young people face both inside and outside of the learning spheres (for a fuller discussion of notions of social justice see Coburn and Gormally, Chapter 4 this volume).

\section{'Caring-for' and caring about others}


'Caring-for' involves face-to-face encounters in which one person attends directly to the needs of another. We learn first what it means to be 'cared-for'; 'then, gradually, we learn both to care for and, by extension, to care about others' (Noddings 2002: 22). It is this 'caring-about' that can be viewed as the cornerstone for our sense of justice. Noddings goes on to assert that care involves two parties and is therefore relational. The first party is the 'one-caring' and the second the 'cared-for', with both parties contributing to the relationship. Motivation to care is directed towards the welfare, protection or enhancement of the 'cared-for' (Noddings 2013).

In the learning spheres care starts with practitioners having a relationship with the young people they are interacting with. In a professional context it is essential that this relationship is underpinned by sound ethics which consider things such as professional boundaries and attitudes including respect for people. When the motivation to care is to put people on the right path or make the right decisions for people, the question as to who decides what the right path or decisions are is paramount. The one caring must respect the right of people to make the decisions that they feel are right for them even if this is over and against what others may want or even need them to do (Sercombe 2010). Without an ethics of care, care can, arguably, be damaging and burdensome to both the one-caring and the cared-for.

\section{Authentic and aesthetic care:}

Duncan-Andrade and Morrell (2008) highlight two forms of caring: authentic caring and aesthetic caring. The former is the foundation of meaningful and reciprocal relationships whilst the essence of aesthetic caring lies in 'an attention to things and ideas' (Valenzuela 1999:22) which can lead to a false sense of caring where those in a position of power perceive themselves as caring but the 'cared for' do not perceive it as such. This is particularly potent in the learning spheres in a target-driven culture where practitioners may become driven by caring about the completion of their course, the achievement of accredited learning or implementation of polices etc. These two forms of caring are illustrated in the following vignette:

At a further education community college attended by young people aged 16-21 years, a young person had arrived for his second of three days per week attendance. The previous day he had sat a test to determine if he 
could move onto the next level of study. On arriving he was told by the tutor that he had failed the test and would have to work through the test again that day. The young person became angry and said that he could not do this and left the building. Working alongside the tutor was a youth work student who had been engaging with the young person for a short time and had started to build a two-way mutually respectful relationship. She felt upset for the young person and decided to follow him out of the building, asking him if he would come back inside for a cup of tea and a chat. The young person did so and, during their conversation, shared that he was currently homeless and sleeping on friends' sofas, due partly to being unable to find hostel accommodation which would also accept his dog. The dog was important to him as he had grown up in care and had no family; to him, the dog was his only family. He explained that he had had very little sleep the night before and could not handle the news he received on first entering the college that day. He said that he so wanted to learn and receive his accreditation but was overwhelmed by the issues of being homeless. The youth work student asked if she could support him to apply to the only hostel in the city that would take his dog, to which he agreed. They did this that day.

The vignette demonstrates how the tutor aesthetically cared about the young person progressing through the 12-week programme, no doubt believing that this would improve the young person's outcomes. However, the success of this example lies with the youth work student who was able to authentically care for the young person and, through a mutually respectful and trusting relationship, support the young person to address the barriers to his learning. If caring had only existed on the aesthetic level, the young person would not have gone on to overcome his issues around homelessness at that time which were preventing him from reaching his selfdefined goal in learning. Aesthetically caring about 'things and ideas' and not authentically caring about people can be counterproductive to achieving the targets and goals prescribed by funders and government bodies. Authentic care has the potential to break down the barriers that impact on young people's learning and result in young people that feel genuinely cared for and, in turn, who become more open to caring about their learning. 
In Archer et al's (2010) study, young people expressed that the teacher-student relationship was a critical factor affecting their engagement with schooling. This relationship involved feeling trusted and listened to, respect and reciprocity. Where relationships were positive young people engaged and attended more regularly. This was not dependent upon the subject but the teacher. An earlier study by Morgan and Morris (1999) also found that when young people were asked why they learnt more in some lessons than others,60 per cent responded that it was something to do with the teacher. Half of the responses were to do with the teaching methods and the other half to do with interpersonal relationships: young people used words such as 'respect', 'kind' and 'nice', and 'having a good time'. It is only through authentically caring that these notions of care can be felt by young people. Building mutually respectful and trusting relationships allows young people to open themselves to learning. In doing so, young people will benefit from being able to show themselves to be ignorant, weak and vulnerable (Batsleer 2008), but in a safe environment.

To emphasize the importance of authentically caring is not to completely disregard the place of aesthetically caring in learning - but it should also be acknowledged that for some practitioners, conflicts between the two may present themselves. In the case of the youth work practitioner, they are firstly concerned with what the young person feels is important for example their interests and relevant issues; as such, their primary client is the young person (Sercombe 2010). This can make it easier to adopt the value base of caring for and about young people in an authentic caring manner. In contrast, other professionals, such as social workers and teachers, often need to balance the various interests of additional stakeholders such as the state (Sercombe 2010). It is important to recognize the conflicts that may arise in adopting a value base of authentically caring for and about young people, due to the need to balance the priorities of stakeholders which demand practitioners to aesthetically care and to see the problem and not the person. Whilst accepting that these conflicts exist, it is maintained that to be able to authentically care for and about young people is a worthwhile goal to strive for. In doing so, it is asserted that young people would achieve far more from their learning if we cared about them, and for them, authentically, given the significant amount of their time spent in the different spheres of learning. Moreover, as the previous vignette demonstrates, within the different 
learning spheres, young people do not exist in a vacuum. We cannot separate lives that exist both inside and outside of learning, and indeed it is essential, in informal and social learning, that they are not decoupled. Thus, it is important to take an interest in young people's lives outside of learning and, through this, young people may develop a sense of being cared for and about.

Within the context of the neoliberal policy agenda that has been driving education and learning over the past three decades, conflicts in caring-for and about young people have intensified. In the context of formal learning, young people are required to practice strict timekeeping, conduct and dress codes; matters such as being late in the morning, or students not having the correct uniform or conducting themselves within defined parameters, can result in punitive sanctions which can have a profound impact on young people's learning. Sanctions are often implemented without caring to find out the reasons for the young person's lateness, incorrect uniform or 'inappropriate' behavior. The practitioner aesthetically cares about the rules instead of authentically caring about the young person and seeking to find out the reasons for their breach of school rules. Perhaps the young person is a carer and needs to get younger siblings ready for school; or is not sleeping properly due to family conflict or abuse. In caring about the rules, the question may not arise of 'does it matter?' if the young person is wearing white socks instead of grey; trainers instead of shoes? Is this going to impact on their own, or others' learning? What will be the impact of a punitive approach - sending the young person home, for example, to change socks, or asking them to remove their trainers for the day? We must care enough about young people to 'find ways to "set them free"' (Shields and Requa 2010: 37) by challenging conformist policies and the micro politics of schooling inflicted on them. The next vignette shows the impact of such punitive policy and practice on a young person, and the barriers these presented to their current and future learning.

At a careers' event at a secondary school one Friday afternoon, a female aged 13 years approached the university stall and entered into a conversation about what she wanted to do after she left school. The girl told the university tutor that she would join the army after school as she had been told by her parents that she would be no good for anything other 
than working on the streets ('prostitution'); whereas her teachers had said that the army would be a better option as she needed 'discipline'. The conversation was progressing well, and the idea of going to university was broached; the girl then realized she needed to leave as she had to attend the school exclusion unit, owing to being late for school that week.

What is striking about this example is not just the punitive regulation of school exclusions in England (Cooper 2002), it also highlights how nobody inside or outside of the learning spheres had any aspiration for this young person, nor did anybody support her to develop her own. The young person could have been 'set free' on this occasion by lifting the punitive sanctions imposed on her for being late for school that week, and allowing her to fully engage in the careers' event. Instead, she was treated as someone without aspiration. Cooper (2011) reports of the caution that was expressed to him by mainstream youth provision managers of not expecting too much of young people and to raise aspirations of young people who were extremely disadvantaged was unrealistic. In practice what Cooper (2011) found was young people did have aspirations and were able to 'debate complex issues and hold refined perspectives (2011:63). This echoes Archer et al's (2010) study with urban working-class young people in London, young people who had been identified as being 'at risk' of dropping out of school and not progressing onto post-16 education, found that despite popular and media representations of urban youth as aimless, hedonistic and without aspiration, a striking feature was the range of 'responsible' aspirations that these young people expressed, with the underpinning motivations of being happy and staying safe.

In setting young people free of oppressive policy, practitioners also need to be aware of the discourse used in learning. The power of language to portray feelings of care or lack of care can be helpful or unhelpful to notions of caring-for and about young people. Duncan-Andrade and Morrell (2008) promote the notion of 'revolutionary love', a love that manifests itself in an absolute belief in the potential of all young people. This requires educators to have energy and passion for learning with a constant search for more effective ways of helping young people to learn and demonstrate their learning both academically and socially. It is acknowledged that this love is not easy, and that it may exist more as an ideal than a reality, but this 
love enables us to become critical educators and agents of social change. Caring about the pedagogical design is a crucial element of this love, and caring about and for young people. This is at the forefront of the following framework proposal for working with young people.

\section{A framework proposal for working with young people}

Smith's (2012) model of animation, reflection and action - alluded to at the start of this chapter - is advocated as a means of enabling practitioners to care about and for young people. It is also relational, and thus supports the two-way caring relationship promoted by Noddings $(2002,2013)$ that requires both authentic and aesthetic caring.

Animation: bringing 'life' into situations, often achieved through offering new experiences.

In animating learning, it is important to recognize that young people learn in different ways. Honey and Mumford (1992) defined four such learning styles: activist, reflector, pragmatist and theorist. Each young person learns best from different learning approaches, such as being given the time to reflect in the case of the reflector; to being able to dive straight into an activity 'hands on' in the case of the activist. Some young people thrive between a mix of styles. As such, it can be assumed that there is no such thing as a 'bad learner', only a 'bad teacher', and therefore it is important to care about not just what young people learn but how they learn. Caring about the process of learning becomes more important than any end goal; it is key, therefore, to trust in the process of learning, in the knowledge that there will be an outcome. In animating learning, we are caring about this process and acknowledging that young people learn more when they perceive something to be interesting or useful to them. The following vignette describes a challenge faced by an educational practitioner in a formal school setting in England.

$\mathrm{Mr} \mathrm{B}$, was required, through the national curriculum, to teach about World War Two. The challenge was to animate a subject which for many young people has, it could be argued, become increasingly disconnected from their lives, with generations that lived through the war ever more absent. 
How do you, therefore, teach such a topic in a way that will come alive for, and resonate with, young people? For several sessions in the autumn term, young people had been learning about World War Two in the classroom. This had been animated with the use of film, arts activities and a field trip to a war museum. Mr B decided to use the old Andersonshelter in the school grounds to further bring this learning alive and, following a week of arts' activities, making gas masks and dressing up as evacuees: then, whilst seated, the class was exposed, without warning, to an air-raid signal that was sounded in the classroom. (Mr B had previously recorded the signal on his mobile phone). 'Quick!', exclaimed Mr B, 'get your gas masks; we need to get to the Anderson shelter'. Everyone, excitedly, made their way across the school field to the Anderson shelter where they sat huddled together whilst Mr B played pre recorded sounds of bombs dropping. This experience allowed the young people to develop a sense of what this must have been like for others in the war; they later reported that they experienced a mix of excitement and fear. Meanwhile, another teacher outside the shelter placed balls on the school field to depict bombs. The all clear signal was sounded and, when everyone emerged from the shelter, they were confronted with the task of navigating their way around the 'bomb site'. The day ended with a reflective discussion about how the young people had felt during these events and, the following week, their learning was further animated through the production of poetry, art work and stories of the experience.

This vignette demonstrates how the practitioner brought life into the situation and created new experiences for those involved. This presented particular learning in a particular context where young people were fortunate to not have lived experiences of war and conflict. It is imperative that in animating learning concerning issues such as war there would have to be caution as to the lived experiences of students. Mr B knew his students and was assured that animating learning in this way would not be overly frightening for them. Through the reflections that followed, the practitioner also learnt more about the young people he was engaged with in the learning process. Thus, learning became a two-way process, built on relationships between the onecaring and the cared-for. Young people's enthusiasm for learning was tangible, and 
they wanted to talk about the experience long after the sessions finished. What might have been an abstract and dry subject was suddenly exciting and alive. In Morgan and Morris' (1999) study, young people reported that they learnt more when learning was fun and animated; moreover, the range of activities was an essential feature of effective learning. What they wanted was active learning. In animating learning, the practitioner must strive to stimulate the students to ask questions and, thereby, encourage them to participate in the process of discovery. Freire and Faundez (1997) argue that education generally consists in finding answers, not asking questions. In asking questions, learning becomes creative and capable of stimulating young people's capacity to experience surprise, and to respond to that surprise, and solve their fundamental existential problems. The act of the cared-for asking questions of the one-caring can, as Young (1999) states, be very reassuring for a young person to sometimes hear, in response to a question, 'I don't know', or 'I never thought of that', as often they are afraid to say these things. This in itself can provoke the very transformation that we must strive for in learning.

Reflection: creating moments and spaces to explore lived experiences.

Reflection is key to both the practitioner's and young person's learning in all spheres. It is in creating moments and spaces to explore lived experiences that people can think about, and make sense of, these experiences before, during and after they occur (Thompson and Pascal 2012, Schon 1983). In doing so, actions and feelings can be analyzed, and a deeper understanding of these experiences developed (Sapin 2013). In order to develop this understanding, Ghaye (2008) classifies five habits of reflection which assert a person should reflect on their values, feelings, thinking, actions and context in order to be able to make sense and understand their experiences. Bolton (2014) asserts the need for both reflection and reflexivity. Reflection allows for an in-depth review of events where the reflector attempts to work out what happened, what they and others involved thought and felt from their different perspectives. Reflexivity involves deeper questioning which focuses on aspects such as 'attitudes, theories in use, values, assumptions, prejudices and habitual actions; to understand our complex roles in relation to others.' (Bolton 2014:7). There are many ways that reflection/reflexivity can be undertaken both individually and in groups. These can include the use of journals, reflective cycle logs 
(see Gibbs cycle of reflection figure 2), supervision, drama, conversation with reflective interrogation, creative writing to name a few (Bolton 2014). Articulating this reflection supports the development of new concepts for application to new experiences (Sapin 2013). This can be conceptualised in Kolb's (1984) learning cycle.

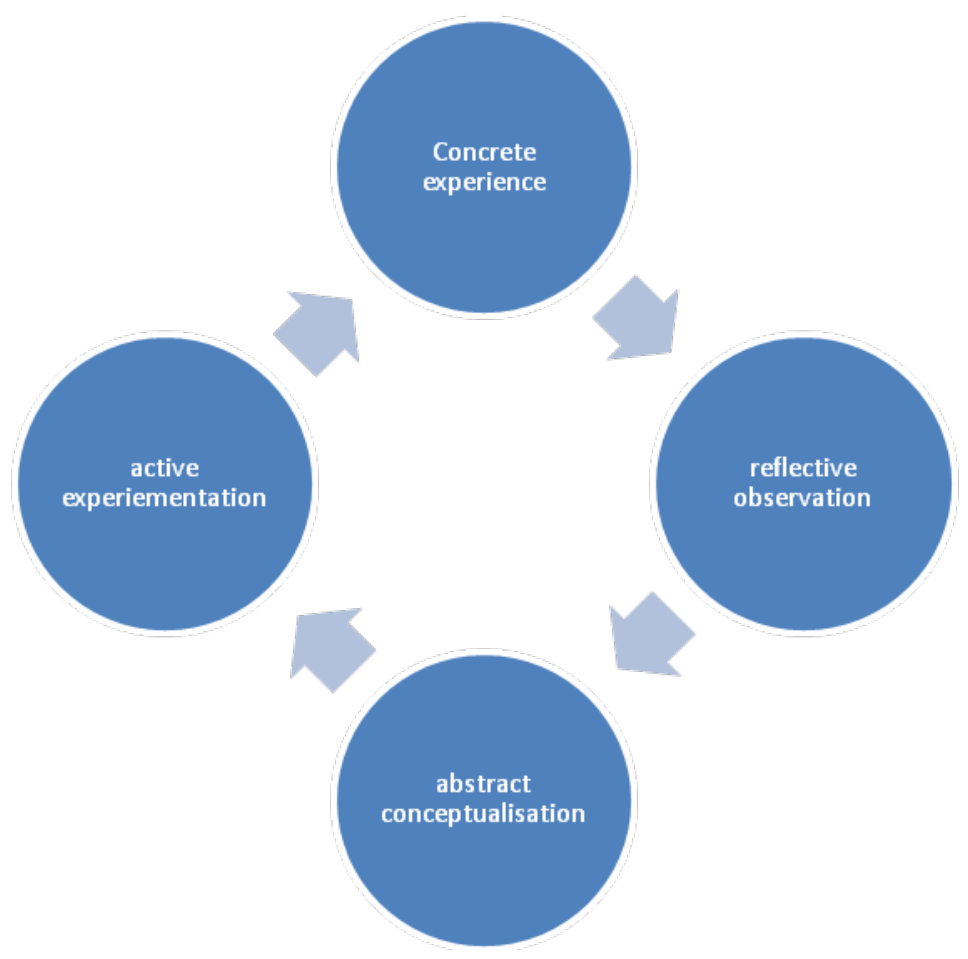

Figure 1: Kolb's Learning cycle (1984)

In engaging with young people in a reflective process, the practitioner will recognize that some young people may wish to start their learning at different points, thus distorting Kolb's learning cycle, they may wish for example to reflect before action (Thompson and Pascal 2012) in order to prepare for the concrete experience; other young people, however, may wish to have the concrete experience first, and reflect both in and on action (Schon 1983). Just as the practitioner needs to care about how they animate young people's concrete experiences, they must also pay attention to how and when they engage in the reflective process with young people. Establishing trust and respectful relationships, whilst creating safe spaces for young people to 
freely express their feelings, is at the heart of this process. Gibbs' (1988) offers aquestioningmodel for reflection which is useful for beginners in the learning spheres to engage in the process of reflection.

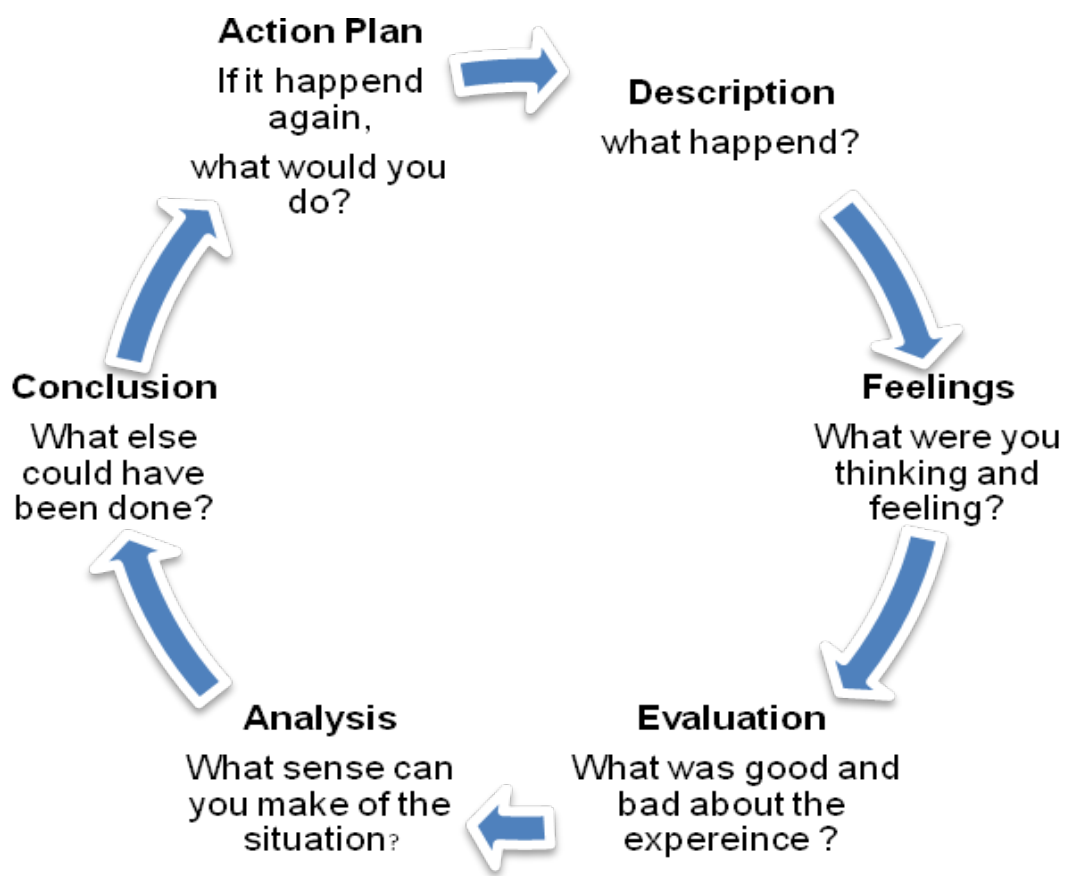

Figure 2: Gibbs reflective cycle (1988)

It is only through critical reflection that we can think imaginatively about how we facilitate creative and inclusive learning, learning that carries possibilities for promoting social justice more widely (Blair and Daly 2005)

Action: working with young people so that they are able to make changes in their lives.

The final component of the framework - taking action - involves working with young people so that they are able to take action on that which they have identified, experienced and reflected on. This critical praxis approach provides a structure for young people to build knowledge, and increase their confidence for personal and social transformation (Portfilio and Carr 2010). Critical praxis develops young people's understanding of complex problems and the notion that these problems require comprehensive solutions that must be revisited, amended and re-applied to 
reach a full result. Vignettes discussed here have demonstrated that the action required is not always linked to the primary focus of learning. It may indeed be action to address an issue which is forming a barrier to learning, or an unjust policy or issue in the community that the young person wishes to take action on. Within a caring relationship the practitioner can respond in ways that support young people to take such action.

\section{Potential conflicts with value-based frameworks}

In a climate of economic austerity and neoliberal social policy, practitioners have greater social issues to deal with but fewer resources, including time, to do so. Hughes et al (2014), in their conversations with community and youth work practitioners, found that there was an overwhelming consensus amongst them of not having the time to 'care'. This was compounded by feelings that they themselves, the practitioners, were not cared about, which prompts the question: in order for a practitioner to care for and about young people, do they also have to be cared for and about? To 'carefor' requires adequate support, resources and a sense of being valued; without these, practitioners may be left with a sense of being overburdened, undervalued and uncared for. Being cared for may manifest itself in the practitioner being given the time, support and resources to be able to care for and about others, within a supportive policy and practice framework.

As has been argued throughout this chapter, the policy and practice climate of target-focused work with young people may present conflicts regarding the value base and framework for that work. Moreover, target-based work invariably requires practitioners to see the problem and not the person; thus, in a prevailing culture that values outputs over process (Ball 2003), people are forced at best into aesthetically caring. Ord (2007) states

the impact of these targets is that they inevitably skew provision, in particular, though the need to meet the accreditation targets....workers in these situations will be forced to choose to work with those young people with whom it is deemed will be willing and able to commit to an accredited programme and not necessarily those who are in most need. (Ord, 2007:88) 
The ability to authentically care where the needs of the cared-for are central and learning is planned with young people's needs in mind and not a pre determined set of targets. This in conjunction with Smith's (2012) framework of animation, reflection and action, willproduce meaningful outcomes for young people. For example, in an alternative education provision for young people with complex issues which, due to funding cuts, was now under resourced, a student practitioner was told by her line manager that there was not time to deal with the outside issues young people brought in with them. Young people were there to engage in accredited learning and if these targets were not achieved then the funding would not be received. 'We don't have time to sort out issues'. Thus those who find themselves working with those young people in most need find themselves in the dilemma of needing to prioritize outcome over process. However, in order for young people to engage effectively in learning they must be able to address the issues/barriers that prevent or hinder their active engagement. These issues may include, for example, homelessness, poverty, abuse or health concerns. When the practitioner cares for and about young people, and supports them to take action on the issues that are important to them, only then will they be able to focus and achieve in learning. A partnership between practitioners in the different learning spheres could be instrumental here.

Within the learning spheres there is the potential for role conflict. Within some formal learning settings, teachers are employed to teach and pastoral teams employed to care. This may be perceived by some as an excuse not to care and to see learning and care as distinct from one another. What has been demonstrated in this chapter is that young people's learning is profoundly impacted by the ability of the teacher to care or not. Conversely, care itself can be conflictual. As Noddings (2013) states, conflict can occur when the 'cared-for' want for something that is not what the 'one caring' thinks is best for him/her, or when several 'cared-for' need incompatible decisions from the 'one caring' and the 'one caring' becomes overburdened. This is why care alone is not enough and should be underpinned within a wider professional ethical framework, which includes such things as respect, a non-judgmental approach, and good professional boundaries as defined by the relevant professional bodies. 
Conflicts may also arise in formal learning with Smith's (2012) framework of animation, reflection and action discussed in this chapter. Issues may present themselves regarding academic freedom, where teachers are required to teach in accordance with a set curriculum with little scope to assert their professional judgment on what they feel is an appropriate way to teach (Savage et al 2012). There may be time constraints imposed on teaching and learning activities, involved activity methods may be more demanding of the practitioners' time in terms of preparation and student involvement as opposed to didactic methods of teaching and learning.

\section{Re-imagining ways of working with youngpeoplewith a common values base of 'care'}

It is the author's hope that, despite the potential conflicts, that this chapter will inspire practitioners to think about how they engage with young people in the different learning spheres. In re-imagining ways of working with young people, the following actions are advocated.

Avoid a deficit approach to young people's learning; all too often the focus is on young people as 'problems' and what they do not know. A positive approach to working with young people would focus on what young people do know, and aim to build on this to make links to the wider social, political and global world and concepts of learning. For all those engaged with young people in learning to see themselves in partnership with young people, where it is acknowledged that young people possess knowledge and solutions that they can share (Duncan-Andrade and Morrell 2008).

Policies, strategies and practice which have left some of the most socially excluded young people failed by the school system - left uneducated, jobless, and without hope and opportunity - need a radical change. Strategies need to be devised which are more supportive of young people, more respectful of social cohesion, justice, wellbeing and democracy.

Reflective practice needs to be the cornerstone of all practice. The resources to support young people's and practitioners' development of reflection and critical praxis needs to be invested in. It is only through critical praxis that new and 
innovative ways of working can be re-imagined. Alongside this investment, care should be given the time and space required, and should be integrated into practitioner training and practice concerning all learning spheres. In doing so, all practitioners need to have an awareness of the issues that impact on young people's lives and an analysis of the wider context. It is important that practitioners can build trusting relationships with young people, and are adequately prepared to support young people to take action on the issues which are important to them.

These may be idealist notions and visions of utopia; nonetheless we must endeavor to ethically care for and about young people. As Green and Christian state:

The greatest gift that we can give is to 'be alongside' another person. It is in times of crisis or achievement or when we have to manage long-term difficulties that we appreciate the depth and quality of having another person to accompany us. (Green and Christian 1998: 21)

This chapter has argued for a common value base of caring for and about young people within three learning spheres prevalent in young people's lives. The learning spheres of formal learning, informal learning and social learning have been defined in the context of young people's lives. Alongside the common values baseis a framework for practice devised by Smith (2012) involving animation, reflection and action. Vignettes provide opportunities to explore the need and scope to re imagine ways of working with young people within the different learning spheres. Inspiring the enrichment of practice through training and ongoing reflection and development of policy within the learning spheres offers the possibility of transforming young people'sexperiences. This transformation will facilitate the emancipatory capacity of learning and its ability to act as an agent of social change. Young people will be empowered to impact on the issues that are important to them and the societies to which they belong. 


\section{References}

P. Allmark (1995) 'Can there be an ethics of care?', Journal of Medical Ethics, 21, 19-24.

L. Archer, S. Hollingworth and H. Mendick, H. (2010) Urban Youth and Schooling: The experiences and identities of educationally 'at risk' young people (Maidenhead: Open University Press).

S.J. Ball (2003) 'The teacher's soul and the terrors of performativity', Journal of Education Policy, 18:2, 215-228.

A. Bandura (1977) Social learning theory (Englewood Cliffs, New Jersey: Prentice Hall).

J. Batsleer (2008) Informal Learning in Youth Work (London: Sage Publications).

Blair, M. and Daly, K. (2005) 'High expectations, respect and commitment' in M. Cole(ed.) Professional Values and Practice: Meeting the standards, $3^{\text {rd }}$ Edn (London: David Fulton Publishers).

G. Bolton (2014) Reflective Practice: Writing and Professional Development, 4th Edn (London: SAGE Publications Ltd)

C. Cooper (2002) Understanding school exclusion: challenging processes of docility, (Nottingham: Education Now Publishing Cooperative)

C. Cooper (2012) Imagining 'radical' youth work possibilities - challenging the 'symbolic violence' within the mainstream tradition in contemporary state led youth work practice in England, (Journal of Youth Studies, 15:1, 53-71

J. Dewey (1963) Experience and Education (New York: Collier Books).

J. Duncan-Andrade and E. Morrell (2008) The Art of Critical Pedagogy: Possibilities for Moving from Theory to Practice in Urban Schools (New York: Peter Lang Publishing).

P. Freire (2006) Pedagogy of the Oppressed30th Anniversary Edn. (London: The Continuum International Publishing GroupLtd).

P. Freire and A. Faundez (1998) Learning to Question: A Pedagogy of Liberation in A. Freire, and D, Macedo. (eds.) (2001) The Paulo Freire Reader (New York: The Continuum International Publishing Group).

T. Ghaye (2008) Building the Reflective Healthcare Organisation (Oxford: Blackwell).

G. Gibbs (1988) Learning by Doing: A guide to teaching and learning methods (Oxford: Further Education Unit, OxfordBrookesUniversity). 
M. Green and C. Christian (1998) Accompanying young people on their spiritual quest (London: National Society/Church House Publishing).

P. Honey and A. Mumford (1992) The manual of learning styles, $3^{\text {rd Edn }}$ (Maidenhead: Peter Honey).

W. Hoppit and K.L. Laland (2013) Social Learning: Introduction to Mechanisms, Methods and Models (New Jersey: Princeton University Press).)

G. Hughes, C. Cooper, S. Gormally and J. Rippingale (2014) 'The state of youth work in austerity England - reclaiming the ability to "care"', Youth \& Policy, 113.

D.A. Kolb (1984) Experiential learning experience as a source of learning and development (New Jersey: Prentice Hall).

C. Morgan and G. Morris (1999) Good Teaching and Learning: Pupils and Teachers Speak (Buckingham: Open University Press).

N. Noddings (2002) Starting at Home. Caring and social policy (Berkeley: University of California Press).

N. Noddings (2013) Caring: A relational approach to ethics and moral education (Berkeley: University of California Press).

J. Ord (2007) Youth Work Process, Product and Practice: Creating an Authentic Curriculum in Work with Young People (Dorset: Russell House Publishing)

B. Porfilio and P. Carr (eds.) (2010) Youth Culture, Education and Resistance: Subverting the Commercial Ordering of Life (Rotterdam: Sense Publishers).

M. Reed, A. Evely, G. Cundill, I. Fazey, J. Glass, A. Laing, J. Newig, B. Parrish, C. Prell and L. Stringer (2010) 'What is social learning?', Ecology and Society, online, http://www.ecologyandsociety.org/vol15/iss4/resp1/ date accessed 19 February 2015

K. Sapin (2013) Essential Skills for Youth Work Practice, $2^{\text {nd }}$ Edn (London: Sage Publications).

T. Savage, M. Savage and D. Armstrong (2012) Teaching in the Secondary School, $7^{\text {th }}$ Edn (Boston: Pearson Education Publishing).

D. Schon (1983) The reflective practitioner (Adershot: Avebury).

H. Sercombe (2010) Youth Work Ethics, London: Sage.

Shields, C.M. and Requa, D. (2010) 'Minoritized Youth, Cultural Capital, And the (Micro) Policy Context of Schooling' in B. Porfilio and P. Carr (eds.) Youth Culture, Education and Resistance: Subverting the Commercial Ordering of Life (Rotterdam: Sense Publishers). 
M.K. Smith (2003/2009) 'Jean Lave, Etienne Wenger and communities of practice', the encyclopedia of informal education,

www.infed.org/biblio/communities_of_practice.htm, date accessed 15 January 2015.

M.K. Smith (2012) 'What is pedagogy?', the encyclopedia of informal education, http://infed.org/mobi/what-is-pedagogy/, date accessed 15 January 2015.

N. Thompson and J. Pascal (2012) 'Developing critically reflective practice', Reflective Practice, 13:2, 311-325.

A. Valenzuela (1999) Subtractive schooling (Albany: SUNNY Press).

K. Young (1999) The Art of Youth Work (Russell House Publishing Ltd: Lyme Regis). 